\title{
Judicial Review of Constitutional Amendments in Turkey
}

\author{
Ergun ÖZBudun*
}

The binding nature of the 'immutable' or 'unamendable' provisions of constitutions is one of most hotly debated problems in constitutional theory and practice. In a sense, this problem is related to the broader one of the inherent tension between democracy and constitutionalism. While democratic principles require that the people as the source of all public powers must have an unlimited constituent power, constitutionalism requires that such power should be exercised only within the limits prescribed by law, including the unamendable provisions of the existing constitution. In particular, since in a democracy all public powers, including the constituent power, should emanate from the people, can this power be limited by constitutional means, and, if not, how can the rights and freedoms of the minorities be protected against the unchecked power of the majority? ${ }^{1}$

Many European countries declare some provisions of their constitutions as unamendable, while many others contain no such clauses. In France (Article 89) and Italy (Article 139) this is limited to the republican form of government. Some constitutions attribute unamendability to the basic principles of democracy and human rights. For example, according to the Constitution of the Czech Republic (Article 9, paragraph 2), 'any changes in the essential requirements for a democratic state governed by the rule of law are unadmissible'. The Constitution of Switzerland (Articles 193,194) stipulates that a total or partial revision of the Federal Constitution may not violate 'the mandatory provisions of international law'. According to Article 79 of the Basic Law of the Federal Republic of Germany, 'amendments to this Basic Law affecting the division of the Federation into Länder, their participation in the legislative process, or the principles laid down in Articles 1 and 20 shall be prohibited'. Article 1 referred to by Article 79 declares the inviolability of the dignity of man, the inviolability and inalienability of human rights, while Article 20 describes the Federal Republic of Germany as a 'democratic and social federal state', stipulates that 'all public authority emanates from the people', and recognizes the right to resist attempts to destroy this constitutional order.

\footnotetext{
* Bilkent University.

${ }^{1}$ For a thorough analysis of the inherent tension between democracy and constitutionalism particularly in the context of constituent power, see Martin Loughlin and Neil Walker (eds), The Paradox of Constitutionalism: Constituent Power and Constitutional Form (Oxford: Oxford University Press, 2007).
}

Özbudun, Ergun. 'Judicial Review of Constitutional Amendments in Turkey'. European Public Law 15, no. 4 (2009): 533-538.

(C) 2009 Kluwer Law International BV, The Netherlands 
Some European democracies define the unamendable clauses more broadly. For example, under the Romanian Constitution of 1991 (Article 148), 'the provisions of this Constitution with regard to the national, independent, unitary, and indivisible character of the Romanian State, the Republican form of government, territorial integrity, independence of the judiciary, political pluralism, and official language shall not be subject to revision. Likewise, no revision shall be made if it results in the suppression of the citizens' fundamental rights and freedoms, or the safeguards thereof'. The Constitution of Ukraine (Article 157) stipulates that 'the Constitution of Ukraine shall not be amended, if the amendments foresee the abolition or restriction of human and citizens' rights and freedoms, or if they are oriented toward the liquidation of the independence or violation of the territorial indivisibility of Ukraine'. Under the Norwegian Constitution (Article 112) constitutional amendments must never 'contradict the principles embodied in this Constitution, but solely related to modifications of particular provisions which do not alter the spirit of the Constitution'. Under the Greek Constitution (Article 110) 'the form of government as a Parlimentary Republic' and a number of provisions referred to by this Article are unamendable. The latter concerns respect for and protection of human being, equality, the right to freely develop one's personality, the inviolability of personal liberty and of the freedom of religion and conscience.

The two European Constitutions that went farthest in extending the scope of unamendable provisions are the Portuguese Constitution of 1976 and the Turkish Constitution of 1982. The former enumerated fifteen items as unamendable principles (Article 290). These included such highly ideological clauses as 'the collectivization of basic means of production and the abolition of monopolies and large estates' and the 'democratic planning of the economy'. The inclusion of such clauses can be explained by the leftist majority in the Constituent Assembly and the pressures and threats of the leftist Armed Forces Movement. ${ }^{2}$ These ideological provisions were later modified, however, by a constitutional revision (new text, Article 288).

The 1982 Turkish Constitution also departed from the tradition of the earlier Republican constitutions by extending the scope of unamendable provisions. While the Constitutions of 1924 and 1961 limited the unamendability clause to the republican form of government, the military founders of the 1982 Constitution extended its scope to the first three articles of the Constitution. In fact, in the preparation of the Constitution, although the civilian Consultative Assembly (wholly appointed by the ruling military junta, the National Security Council) proposed to remain faithful to the tradition of the earlier Constitutions, the Council made not only the republican form of government (Article 1), but also Articles 2 and 3 unamendable (Article 4). Article 2 states that 'the Republic of Turkey is a democratic, secular and social state governed by the rule of law, respectful of human rights, committed to Atatürk nationalism, based on the basic principles referred to in the Preamble, within an understanding of social peace, national

2 Andrea Bonime-Blanc, Spain's Transition to Democracy: The Politics of Constitution-Making (Boulder: Westview Press, 1987), 119, 122 . 
solidarity, and justice'. Article 3 stipulates that the Turkish state 'is an indivisible whole together with its territory and nation. Its language is Turkish'. The Article also describes the flag and the national anthem and declares Ankara as the state capital. Clearly, some of the concepts referred to in Article 2, such as social peace, national solidarity, and justice are extremely vague terms open to very different interpretations. Certain concepts embodied in the Preamble, such as 'Turkish national interests', 'Turkish entity', 'national and moral values of Turkishness', and 'Atatürk's civilizationalism', are even more so. Thus, to render the first three articles unamendable carries with it the danger of making the Constitutional Court the ultimate referee of constitutional revisions and granting it an exceedingly wide margin of appreciation. The problems arising from this state of affairs will be analyzed in greater detail below.

The similarities between the Turkish and Portuguese cases are striking. In both cases, the military exerted strong influence on the constitution-making process, more so in the Turkish case. In both instances, the military sought to instutionalize and freeze its own concept of good society and good polity in the form of unamendable constitutional provisions. The main difference is that while Portugal was able to liquidate this authoritarian legacy through the extensive constitutional revisions of 1982 and 1989, Turkey has not yet succeeded to totally eliminate the legacy of the military regime of 1980-1983.

Some European democracies have chosen, instead of putting absolute material limits on constitutional amendments, to adopt reinforced procedures for constitutional amendments affecting the basic characteristics of the state. For example, in the Russian Federation (Article 135) and Bulgaria (Articles 153,158) such changes can be made not by the qualified majorities of ordinary legislatures, but by a special Constituent Assembly. In Spain, if a total or partial revision affecting the Preliminary Title, Chapter Two Section 1 of Title 1 (fundamental rights, public liberties) or Title 2 (the Crown) is proposed, the principle shall be approved by a two-thirds majority of the members of each House, and the Cortes shall immediately be dissolved. The Houses elected must ratify the decision and proceed to examine the new Constitutional text, which must be approved by a twothirds majority of the members of both Houses. Once the amendment has been passed by the Cortes Generales, it shall be submitted to ratification by referendum (Article 168). Thus, it seems that there is no standard European practice on the unamendable clauses.

A closely related question of even greater practical importance is the sanction of unamendable clauses if the constitution embodies them. Interestingly, while such clauses exist in the constitutions of many European democracies, only very few (Turkey, Article 148; Ukraine, Article 159; Moldova, Article 141; Romania, Article 144a; and Azerbaijan, Article 153) of them have empowered their constitutional courts to review the compatibility of constitutional amendments with the unamendable clauses, none of which can be considered a highly institutionalized and stable democracy. Besides, in four of them (with the exception of Turkey) the review of the constitutionality is preventive (a priori) not repressive (a posteriori). In the absence of a clear empowering constitutional norm, most constitutional courts (those of France, Hungary, Slovenia, and Ireland) refused to review the compatibility of constitutional amendments with the unamendable provisions. 
On the other hand, the German Constitutional Court saw such review within its competence, arguing that the phrase in the Constitution 'to review of the conformity of federal and Land laws with this Basic Law' also included the constitutional amendments, as well as ordinary laws. However, the German Court has not so far annulled a constitutional amendment on such grounds. ${ }^{3}$

The competence of the Constitutional Court with regard to constitutional amendments has long been a hotly debated issue in Turkey. The Constitution of 1961 had no explicit provision concerning the judicial review of constitutional amendments. Theoretically speaking, such review would be possible only if one adopts the existence of suprapositive constitutional norms or of a hierarchy of norms within the constitution itself. In the Turkish constitutional system no such hierarchy was established and it was commonly agreed that all constitutional norms had equal legal value. Only, Article 9 of the 1961 Constitution had stipulated that Article 1 on the republican form of government was unamendable and that no proposal could be made in order to amend it. The Constitutional Court in a 1970 ruling invalidated a constitutional amendment arguing that the unamendable republican form of government should be construed to include the characteristics of the Republic enumerated in Article 2, namely a national, democratic, secular, social state, based on human rights and the rule of law. Thus, the Court argued that an amendment incompatible with any one of these characteristics would be against Article 9 which bans amendments altering the republican form of government. ${ }^{4}$ Evidently, this interpretation gave the Constitutional Court the competence to invalidate almost any constitutional amendment, since it is hard to conceive any constitutional amendment that does not touch upon one of these characteristics.

The legislative assembly reacted to this ruling by a constitutional amendment adopted in 1971 which restricted the review powers of the Court over constitutional amendments to a merely procedural review, namely to a review of whether the procedural requirements for such amendments were complied with. However, the Court again struck down four constitutional amendments in 1975, 1976 and 1977. This time the Court's argument was that the unamendability clause concerning the republican form of government was not only a substantive, but also a procedural norm, since such a proposal could not even be submitted under Article 9 of the Constitution. Therefore, any amendment that is incompatible with the characteristics of the Republic enumerated in Article 2 would be procedurally unconstitutional and null and void. ${ }^{5}$

The political elites reacted to these rulings once more in the Constitution of 1982. Article 148 of the Constitution limits the procedural review of the Court to ascertain whether the quorums for the amendment proposal and its adoption are complied with $52-64$

${ }^{3}$ Kemal Gözler, Judicial Review of Constitutional Amendments: A Comparative Study (Bursa: Ekin Press, 2008), 22-23,

${ }^{4}$ Constitutional Court decision, E. 1970/1, K 1970/31, 16 Jun. 1970, AMKD (Reports of the Constitutional Court), no. 8,323 .

5 Constitutional Court decisions, E. 1973/19, K. 1975/87, 15 Apr. 1975, AMKD, no.13, 430-431; E. 1976/38, K. 1976/46, 12 Oct. 1976, AMKD, no. 14, 252-286; E. 1976/43, K. 1977/4, 27 Jan. 1977, AMKD, no. 15, 106-131; E. $1977 / 82$, K. 1977/117, 27 Sep. 1977, AMKD, no.15, 444-464. 
and whether the ban on the use of the urgent procedure (debating a proposal once instead of twice) in the Assembly debates on the amendment bill is violated or not. Furthermore, Article 149 stipulated that the Court could invalidate a constitutional amendment only by a two-thirds majority of its members. The 2001 constitutional amendment reduced this qualified majority to three-fifths. Thus, it appeared that the controversy over the judicial review of constitutional amendments had ended. Since the adoption of the 1982 Constitution the Court has not until 2008 invalidated any constitutional amendment, and in the three cases referred to it, it decided that the alleged procedural irregularity was not among the ones covered by Article $148 .{ }^{6}$

However, the Turkish Court suddenly changed its opinion in a ruling on 5 June 2008 and invalidated a constitutional amendment changing Articles 10 and 42 of the Constitution. The change in Article 10 on equality involved the addition of the phrase 'in the utilization of all public services', and the change in Article 42 consisted of the addition of the sentence "no one shall be deprived of his/her right to higher education unless expressly prohibited by law'. Clearly, the purpose of the amendment was to abolish the ban on wearing headscarves for female university students. It should be recalled that the ban itself was not introduced by a law but by the two rulings of the Constitutional Court rendered in 1989 and 1991. The Court first considered the question of its competence and, returning to its jurisprudence in the 1970s, ruled that incompatibility with the first three unamendable articles was not only a matter of substance, but also a matter of form (procedure). Therefore, the Court considered itself competent to review the case. It then proceeded to examine the case on substantive grounds and concluded that the abolition of the headscarf ban at univerisities was against the principle of secularism mentioned in the unamendable Article 2 and that therefore the constitutional amendment was unconstitutional. ${ }^{7}$

This ruling of the Constitutional Court was highly controversial both on procedural and substantive grounds. Procedurally, it seems impossible to maintain the argument it put forward, during the 1961 Constitution, itself of very dubious legal validity. The 1961 Constitution as amended in 1971 limited the Court's competence over constitutional amendments to a merely procedural review. Article 148 the 1982 Constitution, on the other hand, clearly specified what kind of procedural irregularities (irregularities of form) are subject to the Court's review. These are whether the quorums for the amendment proposal and for its adoption are complied with, and whether the proposal is debated twice. The Constitution has no explicit or implicit rule empowering the Court to review the compatibility of a constitutional amendment with the unamendable articles of the Constitution. Therefore, the decision of the Court is not only inconsistent with its earlier rulings in the 1982 Constitution period but also amounts to a 'usurpation of power' since it is in violation of the explicit text of Article 148.

${ }^{6}$ Constitutional Court decisions, E. 1987/9, K. 1987/15, 18 Jun. 1987, Resmi Gazete (Official Gazette), 4 Sep. 1987, no. 19564, 22-26; E. 2007/72, K. 2007/68, 5 Jul. 2007, Resmi Gazete, 7 Aug. 2007, no. 26606; E. 2007/99, K. 2007/86, 27 Nov. 2007, Resmi Gazete, 16 Feb. 2008, no. 26792.

7 Constitutional Court decision, E. 2008/16, K. 2008/116, 5 Jun. 2008, Resmi Gazete, 22 Oct. 2008, no. 27032. 
The Court's decision can also be criticized on substantive grounds. To argue that permitting female university students to wear headscarves is tantamount to undermining the secular character of the state is a reflection of a militant and assertive notion of secularism with no parallel in any Western democracy. In fact, no such ban exists at the university level in any Member State of the Council of Europe.

As a result of this decision, the Turkish Constitutional Court seems to have acquired almost total control over the constitutional amendment process. Since the characteristics enumerated in Articles 2 and 3 are so vague and broad, almost no constitutional amendment can be conceived that is not in one way or another related to one of these characteristics. Such an interpretation practically deprives the people and/or its elected representatives of their constituent power which in a democracy should ultimately belong to them. As stated at the beginning, constitutional democracy requires a balance between popular power and the institutional channels through which it should be exercised. But to limit the former to such an extent can no longer be called a requirement of constitutional democracy but an example of juristocracy. Perhaps the most fitting formula for constitutional democracy is, in the words of a leading American scholar, "judicial review without judicial supremacy'. ${ }^{8}$ Based on humanity's two-century-old experience in constitutionalism one may conclude by repeating the classical formula that constitutions should be rigid enough to ensure the stability of the basic structure of the state and to protect minority rights against the unbridled power of the majorities but flexible enough not to prevent peaceful and democratic constitutional change in response to changing societal needs and demands.

${ }^{8}$ Larry D. Kramer, The People Themselves: Popular Contitutionalism and Judicial Review (Oxford: Oxford University Press, 2004), 249-253. 